\title{
KAJIAN AKTIVITAS ANTIBAKTERI EKSTRAK ANGKAK TERHADAP PERTUMBUHAN BAKTERI Bacillus cereus DAN Bacillus stearothermophillus
}

\author{
Enny Sumaryati*) dan Sudiyono*) \\ ${ }^{*}$ Dosen Fakultas Pertanian ,Universitas Widyagama Malang \\ e-mail : enny.dosenuwg@yahoo.co.id \\ e-mail : dionuwg@yahoo.com
}

\begin{abstract}
Abstrak
Penggunaan zat pengawet sintetis pada makanan oleh produsen semakin meresahkan meskipun pemakaiannya diijinkan karena berdampak negatip pada kesehatan konsumen. Oleh karena itu, upaya pemanfaatan pengawet alami sebagai pengganti pengawet sintetis sangat perlu dilakukan. Angkak memiliki daya kelarutan yang tinggi, stabil, mudah dicerna, dan tidak bersifat karsinogen. Angkak memiliki aktivitas sebagai antibakteri dan jamur, karena adanya senyawa Monascidin A. yaitu senyawa yang bersifat antibiotik, yang mampu menghambat bakteri Bacillus, Pseudomonas dan Streptococcus (Steinkraus,. 1983). Angkak terbukti dapat menghambat pertumbuhan bakteri perusak seperti Bacillus cereus dan Bacillus stearothermopillus ( Astawan, 2006). Bacillus cereus telah dikenali sebagai salah satu penyebab keracunan pada makanan, Sedangkan Bacillus stearothermophilus dikenal sebagai penyebab keasaman dari makanan kaleng. Oleh karena itu ekstrak angkak merupakan alternatif pengganti zat pengawet sintetis sehingga perlu dilakukan penelitian untuk mengetahui berapa konsentrasi optimal ekstrak angkak yang bisa menghambat pertumbuhan bakteri Basillus cereus dan Bacillus stearothermophillus. Tujuan dari penelitian ini adalah untuk memperoleh konsentrasi ekstrak angkak yang tepat untuk menghambat pertumbuhan bakteri Bacillus cereus dan Bacillus stearothermophillus. Antibakteri yang diuji adalah ekstrak angkak dengan mulai konsentrasi $0 \%$ sampai diperoleh konsentrasi angkak dimana larutan uji antibakteri tetap jernih tidak ada pertumbuhan bakteri. Mikroba yang digunakan dalam uji ini adalah Basillus cerius dan Basillus stearothermophilus. Hasil penelitian menyatakan bahwa konsentrasi 4\% ekstrak angkak merupakan Kadar hambat minimum (KHM) pertumbuhan Bacillus cereus sedangkan Bacillus stearothermophilus mempunyai kadar hambat minimum (KHM) 20\% konsentrasi ekstrak angkak. Kadar Bunuh Minimum (KBM) Ekstrak beras angkak terhadap Bacillus cereus adalah konsentrasi $10 \%$ b/v dan untuk Bacillus stearothermophillus adalah konsentrasi 50\% $\mathrm{b} / \mathrm{v}$.
\end{abstract}

Kata kunci : ekstrak angkak, antibakteri, Bacillus cereus, Bacillus stearothermophilus

\section{PENDAHULUAN}

Penggunaan zat pengawet sintetis pada makanan oleh produsen semakin meresahkan meskipun pemakaiannya diijinkan karena berdampak negatip pada kesehatan konsumen. Jenis bahan pengawet sintetis yang diizinkan dan lazim digunakan dalam industri makanan adalah asam benzoat atau garam-garam benzoat (kalium benzoat, kalsium benzoat, natrium benzoat); garam-garam sulfit (kalium sulfit, kalium bisulfit, kalium metabisulfit); nitrat dan nitrit; belerang dioksida. Pengawet yang bukan untuk makanan, seperti formalin dan boraks, meskipun dilarang, pada kenyataannya masih banyak produsen makanan yang masih 
menggunakan untuk pengawet makanan. Adanya kenyataan tersebut tentu saja sangat meresahkan masyarakat yang ingin hidup sehat. Oleh karena itu, upaya pemanfaatan pengawet alami sebagai pengganti pengawet sintetis sangat perlu dilakukan. Seiring dengan berkembangnya slogan back to basic, penggunaan angkak sebagai pewarna alami dan pengawet alami mulai dilirik masyarakat. Angkak selain berfungsi sebagai pewarna alami, angkak juga memiliki aktivitas sebagai antibakteri (Nurika, 2000). Angkak memiliki daya kelarutan yang tinggi, stabil, mudah dicerna, dan tidak bersifat karsinogen. Berdasarkan aktivitasnya zat antibakteri dibedakan menjadi dua jenis, yaitu bakteriostatik dan bakteriosida . Bakteriostatik adalah zat antibakteri yang memiliki aktivitas menghambat pertumbuhan bakteri (menghambat perbanyakan populasi bakteri), namun tidak mematikan. Sedangkan bakterisida adalah zat antibakteri yang memiliki aktifitas membunuh bakteri (Madigan, 2005).

Angkak memiliki aktivitas sebagai antibakteri karena adanya senyawa Monascidin A, yaitu senyawa yang bersifat antibiotik yang mampu menghambat bakteri dari genus Bacillus. Bakteri Bacillus adalah bakteri gram positip. Adanya aktivitas antibakteri tersebut memungkinkan adanya efek preservatif dari penggunaan pada produk fermentasi Monascus (Behr, 1998). Hasil penelitian menunjukkan bahwa produk minuman sari kacang merah control pada suhu ruang bertahan 7 jam, penambahan angkak 1 persen bertahan 13 jam, penambahan propionate 0,1 persen bertahan selama 23 jam ( Tandijo, 2011). Angkak terbukti dapat menghambat pertumbuhan bakteri perusak seperti Bacillus cereus dan Bacillus stearothermopillus (Astawan, 2006). Bacillus cereus telah dikenali sebagai salah satu penyebab keracunan pada makanan, sehingga mikroorganisme ini telah menarik banyak perhatian dan menjadi salah satu penyebab keracunan pada pangan yang termasuk sering ditemukan. Sedangkan Bacillus stearothermophilus dikenal sebagai penyebab keasaman dari makanan kaleng karena fermentasi gula yang terkandung pada pangan. Bakteri termofilik, seperti Bacillus stearothermophilus menyebabkan busuk asam (flat sour) pada makanan kaleng berasam rendah. Oleh karena itu ekstrak angkak merupakan alternative pengganti zat pengawet sintetis yang diketahui bersifat karsinogen, sehingga perlu dilakukan penelitian untuk mengetahui berapa konsentrasi minimum ekstrak angkak yang bisa menghambat pertumbuhan bakteri Bacillus cereus dan Bacillus stearothermophillus dan berapa konsentrasi minimum ekstrak angkak yang dapat membunuh bakteri Bacillus cereus dan Bacillus stearothermophillus.

\section{METODE PENELITIAN}

Metode yang digunakan dalam penelitian ini adalah metode Ilusi . Antibakteri yang diuji adalah ekstrak angkak dengan mulai konsentrasi $0 \%$ sampai diperoleh konsentrasi angkak dimana larutan uji antibakteri tetap jernih 
tidak ada pertumbuhan bakteri. Mikroba yang digunakan dalam uji ini adalah Basillus cerius dan Basillus stearothermophilus.

\section{Pelaksanaan Penelitian}

\section{a. Pengumpulan dan Penyiapan Bahan}

Sampel dalam penelitian ini berupa beras angkak yang diperoleh dari Apotek Sari di Malang. Beras angkak tersebut di ekstrak dan diteliti aktivitasnya sebagai antibakteri. Kultur murni bakteri Bacillus cereus dan Bacillus stearothermophilus diperoleh dari Laboratorium mikrobiologi Fakultas Kedokteran Universitas Brawijaya Malang.

b. Ekstraksi Angkak (Ramadhan, Radiati dan Thohari . 2011)

Angkak diblender hingga halus, bubuk angkak di campur dengan ethanol $50 \% \quad$ menggunakan perbandingan 1:4, larutan bubuk angkak dipanaskan dan diaduk hingga rata selama kurang lebih 1 jam dengan suhu $70^{\circ} \mathrm{C}$, dipisahkan antara endapan angkak dengan ekstrak angkak dengan corong yang dilapisi kertas saring, filtrat angkak dipanaskan kurang lebih 30 menit tanpa dilakukan pengadukan dengan suhu $60^{\circ}-80^{\circ} \mathrm{C}$ sampai volume tinggal $25 \%$.

Ekstrak angkak yang diperoleh kemudian diencerkan sampai dengan kadar yang dikehendaki dan siap untuk diteliti.

\section{c. Uji Mikrobiologi}

Semua peralatan yang akan dipergunakan dicuci bersih, dikeringkan dibungkus kertas coklat dan dterilkan dengan oven pada suhu $200^{\circ} \mathrm{C}$ selama 1-2 jam.

Sedangkan bahan yang akan dipergunakan untuk uji mikrobiologi ( media NA, NB dan ekstrak angkak) disterilkan dengan autoklave pada suhu $121^{\circ} \mathrm{C}$ selama $15-20$ menit.

\section{d. Penyiapan Stock Bakteri}

Bacillus cereus (Biakan murni )
Bacillus stearothermophilus ( Biakan murni )

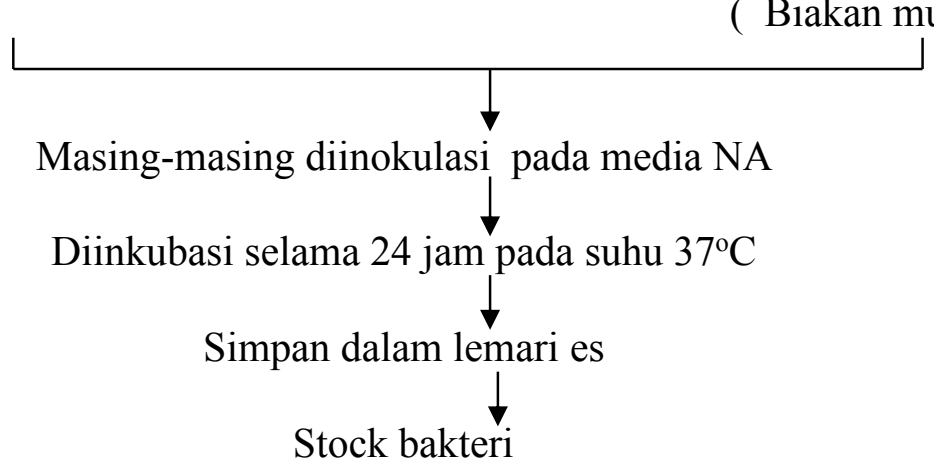

Gambar 1. Skema Penyiapan Stok bakteri 
Jurnal Teknologi Pangan Vol.6 No.1

Januari 2015

\section{Pembuatan Suspensi Bakteri}

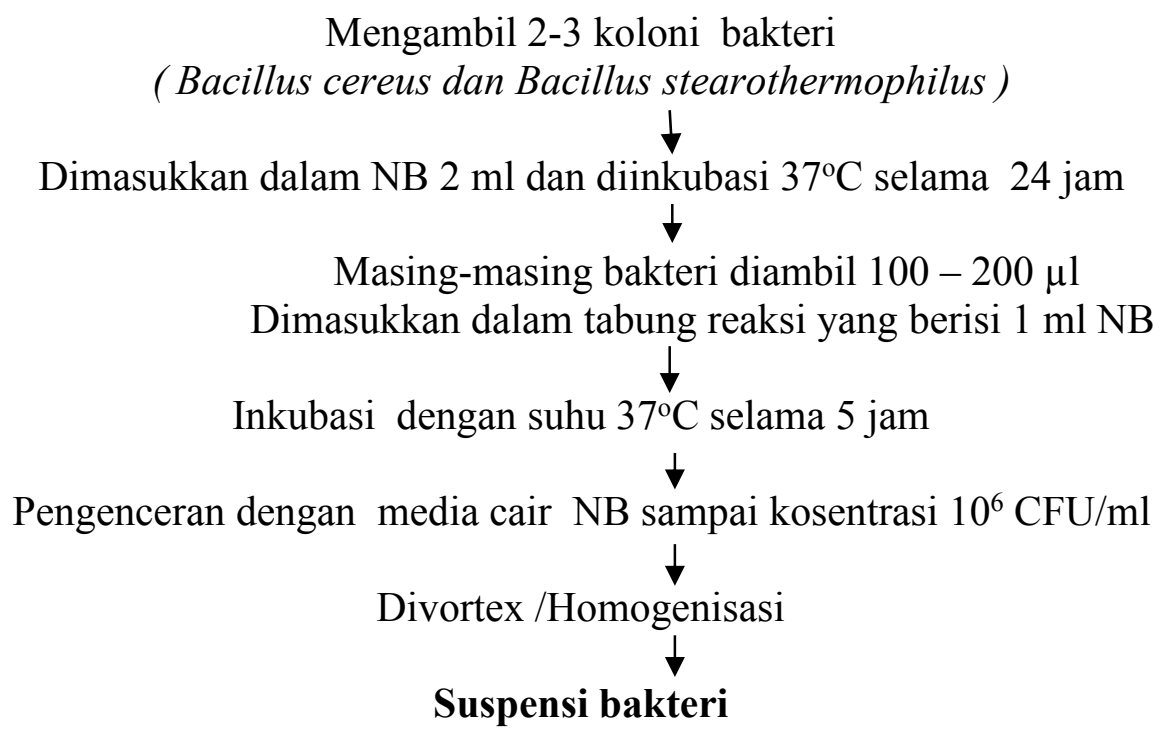

Gambar 2. Skema pembuatan suspensi bakteri

\section{e. Uji Antibakteri}

Metode yang digunakan dalam penelitian ini adalah Metode Ilusi. Metoda ini mengukur MIC (minimum inhibitory concentration $\}$ atau kadar hambat minimum (KHM) dan MBC (minimum bactercidal concentration) atau kadar bunuh minimum (KBM). Larutan antibakteri (ekstrak angkak) diencerkan dengan aquades steril hingga diperoleh beberapa macam konsentrasi yaitu $0 \%, 2 \%, 4 \%, 6 \%$, $8 \%, 10 \%$ ( untuk uji Bacillus cereus ) dan konsentrasi $0 \%, 10 \%, 20 \%, 30 \%$, 40\% dan 50\% (untuk uji Bacillus stearothermophillus ),dimana setiap konsentrasi dibuat 4 ulangan. Kemudian masing-masing konsentrasi ditambahkan suspensi bakteri uji dalam media cair NB dan divorteks supaya homogen selanjutnya diinkubasi suhu $37^{\circ} \mathrm{C}$ selama 24 jam. Diamati ada atau tidaknya pertumbuhan bakteri, yang ditandai dengan terjadinya kekeruhan. Larutan uji senyawa antibakteri pada kadar terkecil yang terlihat jernih tanpa adanya pertumbuhan bakteri uji, ditetapkan sebagai Kadar Hambat Minimal (KHM). Dua belas tabung reaksi berisi $5 \mathrm{ml}$ media $\mathrm{NB}$ yang telah ditambahkan dengan 12 seri konsentrasi ekstrak angkak dan kultur bakteri, kemudian diukur Optical Density (OD) bakteri dengan menggunakan spektrofotometer $(\lambda 625$ $\mathrm{nm})$ sebagai pembanding sebelum perlakuan atau kontrol. Dua belas tabung reaksi lainnya, diinkubasi selama 24 jam pada suhu $37^{\circ} \mathrm{C}$ dalam inkubator.

Hasil inkubasi diukur Optical Density (OD) bakteri dengan menggunakan spektrofotometer $(\lambda 625$ nm), sebagai pembanding sesudah perlakuan inkubasi. KHM ditentukan dengan membandingkan OD setelah perlakuan inkubasi dikurangi OD sebelum perlakuan. Apabila terdapat konsentrasi terendah yang menghambat pertumbuhan bakteri, ditunjukkan dengan tidak adanya kekeruhan OD bakteri adalah $\leq 0$ ), 
maka didapatkan Konsentrasi Hambat Minimal (KHM). Larutan yang ditetapkan sebagai KHM tersebut selanjutnya dikultur ulang pada media NA tanpa penambahan bakteri uji ataupun larutan antibakteri ( ekstrak angkak), dan diinkubasi selama 24 jam.pada suhu $37^{\circ} \mathrm{C}$, kemudian hitung koloni yang tumbuh. Media Nutrient Agar yang tidak terdapat pertumbuhan bakteri setelah inkubasi ditetapkan sebagai Kadar Bunuh Minimal (KBM) (Pratiwi, 2008).

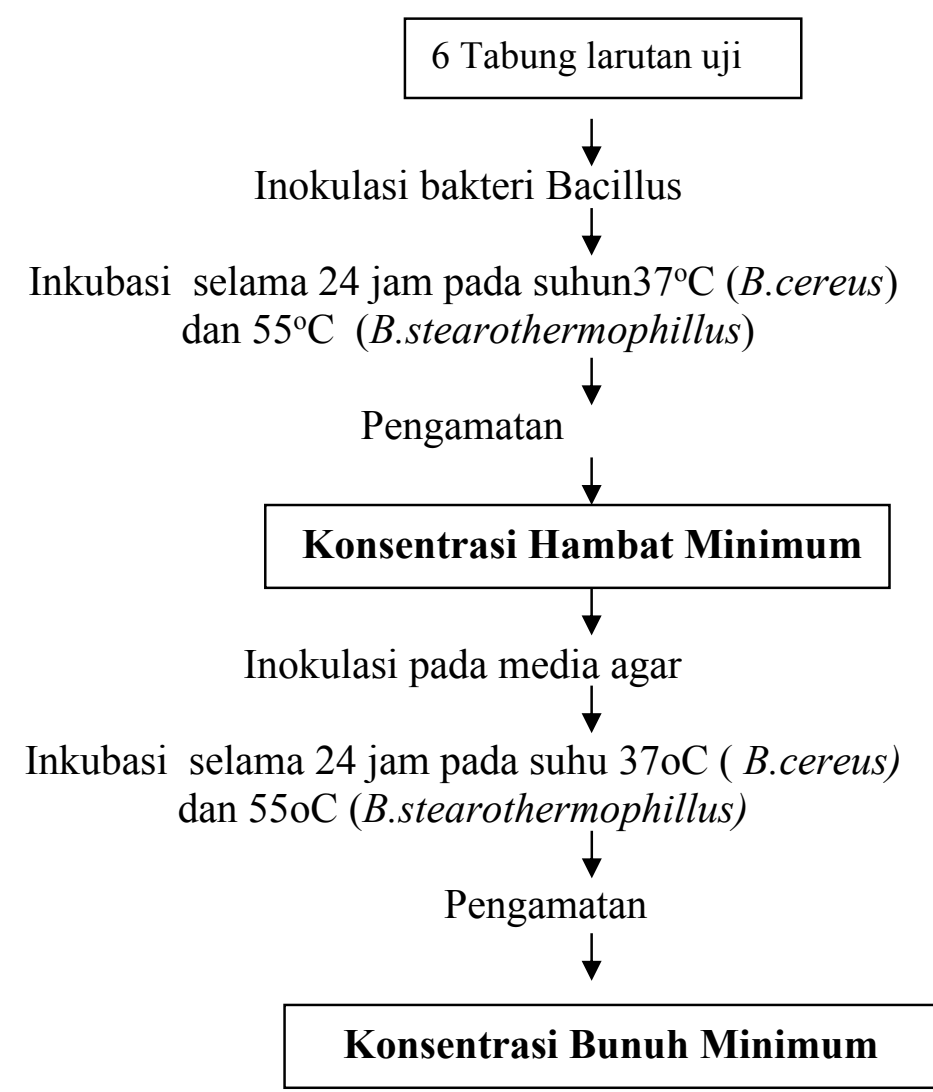

Gambar 3. Skema Penentuan KHM dan KBM

\section{f. Analisis Data}

Data yang diperoleh ditabulasi kemudian KHM ditetapkan berdasarkan kekeruhan pada masingmasing sampel dalam tabung uji. Dari metode dilusi cair ini masing-masing sampel dalam tabung uji diinokulasi pada media padat Nutrient Agar dengan metode tuang dan kemudian diinkubasi . Hasilnya dibandingkan dengan Kontrol. KBM ditetapkan berdasarkan ada tidaknya pertumbuhan bakteri pada media padat dalam cawan petri.

\section{HASIL DAN PEMBAHASAN}

Penelitian dilakukan untuk mengetahui aktivitas antibakteri ekstrak angkak terhadap bakteri yang menyebabkan pembusukan. Apabila aktivitasnya dapat menghambat atau membunuh bakteri, maka dapat diaplikasikan sebagai bahan pengawet makanan alami. 


\section{Pembuatan Ekstrak Angkak}

Angkak diblender hingga halus, bubuk angkak di campur dengan ethanol $\quad 50 \% \quad$ menggunakan perbandingan 1:4, larutan bubuk angkak dipanaskan dan diaduk hingga rata selama kurang lebih 1 jam dengan suhu $70^{\circ} \mathrm{C}$, dipisahkan antara endapan angkak dengan ekstrak angkak dengan corong yang dilapisi kertas saring, filtrat angkak dipanaskan kurang lebih 30 menit tanpa dilakukan pengadukan dengan suhu $60^{\circ}-80^{\circ} \mathrm{C}$ sampai volume tinggal $25 \%$. Ekstrak angkak yang dihasilkan siap untuk digunakan sebagai agen antibakteri

\section{Uji Aktivitas Antibakteri}

Uji aktivitas antibakteri ekstrak angkak terhadap bakteri Bacillus cereus dan Bacillus stearothermophillus dilakukan dengan metode dilusi. Pada pemeriksaan aktivitas antibakteri secara dilusi digunakan kontrol sebagai pembanding yaitu menggunakan media Nutrient Broth untuk penentuan Kadar Hambat Minimum dan media Nutrient Agar untuk penentuan Kadar Bunuh Minimum.

Penentuan Kadar Hambat Minimum (KHM) pada pengujian aktivitas antibakteri dengan metode dilusi cair, parameter yang digunakan adalah kekeruhan ( ada pertumbuhan bakteri) dan kejernihan ( tidak ada pertumbuhan bakteri), yang terlihat setelah diinkubasi selama 24 jam pada suhu $37^{\circ} \mathrm{C}$ untuk bakteri Bacillus cereus dan pada suhu $55^{\circ} \mathrm{C}$ untuk bakteri Bacillus strearothermophilus. Nilai KHM ditentukan dengan mengamati konsentrasi terendah antibakteri pada media cair yang masih jernih menunjukkan tidak adanya pertumbuhan bakteri,

Hasil uji aktivitas antibakteri didapatkan konsentrasi 4\% ekstrak angkak merupakan Konsentrasi hambat minimum (KHM) pertumbuhan Bacillus cereus( Gambar 4. dan Tabel 1 ).

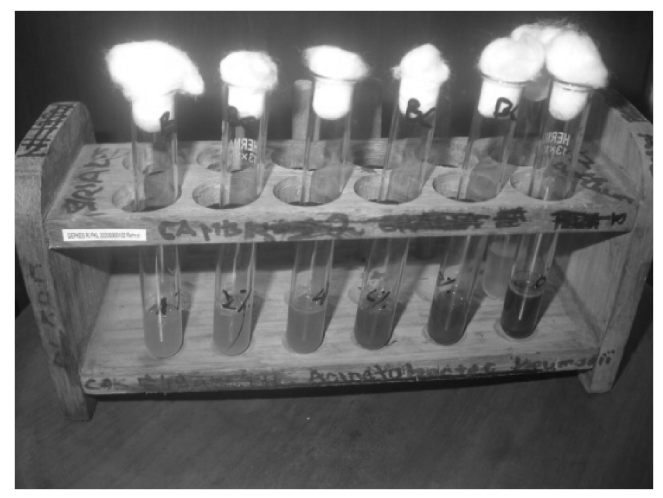

Gambar 4. Hasil Uji antibakteri Bacillus cereus dengan konsentrasi angkak $0 ; 2 ; 4 ; 6 ; 8 ; 10 \%$ dalam media cair 
Tabel 1. Hasil Uji Anti Bakteri Angkak Terhadap Pertumbuhan Bacillus cereus dengan Metode Dilusi Tabung

\begin{tabular}{|c|c|c|c|c|c|c|}
\hline \multirow[t]{2}{*}{$\begin{array}{c}\text { KONSENTRASI } \\
\text { Angkak }\end{array}$} & \multicolumn{4}{|c|}{$\begin{array}{c}\text { REPLIKA } \\
\text { SI }\end{array}$} & \multirow[t]{2}{*}{$\begin{array}{c}\text { RERAT } \\
\text { A }\end{array}$} & \multirow[t]{2}{*}{$\begin{array}{c}\text { CFU/PLAT } \\
\text { E }\end{array}$} \\
\hline & I & II & III & IV & & \\
\hline $0 \%$ & 283 & 276 & 259 & 271 & 272,25 & $2,7.10^{7}$ \\
\hline $2 \%$ & 234 & 210 & 220 & 217 & 220,25 & $2,2.10^{5}$ \\
\hline $4 \%$ & 117 & 132 & 128 & 109 & 121,602 & $1,2.10^{4}$ \\
\hline $6 \%$ & 34 & 29 & 37 & 47 & 36,851 & $3,6.10^{2}$ \\
\hline $8 \%$ & 6 & 7 & 4 & 6 & 5,75 & $5,8.10^{1}$ \\
\hline $10 \%$ & 0 & 0 & 0 & 0 & 0 & 0 \\
\hline
\end{tabular}

Sedangkan stearothermophilus konsentrasi hambat minimum (KHM) $20 \%$ ekstrak angkak. Hal ini diperoleh dengan melihat kejernihan media setelah masa inkubasi 24 jam ( Gambar 9 ). Hasil inkubasi diukur Optical Density(OD) bakteri dengan menggunakan spektrofotometer $(\lambda 625$ $\mathrm{nm})$, sebagai pembanding sesudah perlakuan inkubasi. KHM ditentukan dengan membandingkan OD setelah perlakuan inkubasi dikurangi OD sebelum perlakuan. Apabila terdapat konsentrasi terendah yang menghambat pertumbuhan bakteri, ditunjukkan dengan tidak adanya kekeruhan (jernih) OD bakteri adalah $\leq 0)$. Hal ini bisa dilihat pada Gambar 5 dan Tabel 2.

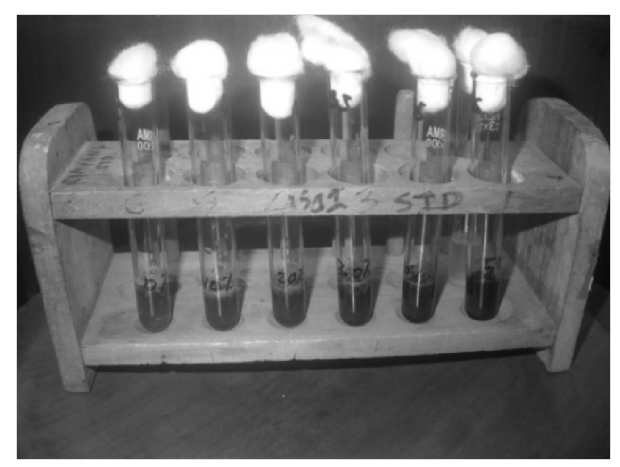

Gambar 5. Hasil Uji antibakteri Bacillus stearothermophilus dengan konsentrasi angkak 0;10;20;30;40;50\% 
Jurnal Teknologi Pangan Vol.6 No.1

Januari 2015

Tabel 2. Hasil Uji Anti Bakteri Angkak Terhadap Bacillus stearothermophillus dengan Metode Dilusi Tabung

\begin{tabular}{|c|c|c|c|c|c|c|}
\hline \multirow{2}{*}{ KONSENTRASI Angkak } & \multicolumn{3}{|c|}{ REPLIKASI } & \multirow[b]{2}{*}{ IV } & \multirow{2}{*}{ RERATA } & \multirow{2}{*}{ CFU/PLATE } \\
\hline & I & II & III & & & \\
\hline $0 \%$ & 299 & 286 & 303 & 291 & 294,75 & $2,9.10^{7}$ \\
\hline $10 \%$ & 237 & 221 & 235 & 251 & 236 & $2,4.10^{5}$ \\
\hline $20 \%$ & 111 & 117 & 121 & 128 & 119,25 & $1,2.10^{3}$ \\
\hline $30 \%$ & 10 & 13 & 9 & 5 & 9,25 & $9,3.10^{1}$ \\
\hline $40 \%$ & 1 & 2 & 4 & 2 & 2,25 & $2,5.10$ \\
\hline $50 \%$ & 0 & 0 & 0 & 0 & 0 & 0 \\
\hline
\end{tabular}

Hasil uji antibakteri diperoleh Konsentrasi Bunuh Minimum (KBM) untuk Bacillus cerius adalah $10 \%$ (Gambar 6) dan untuk Bacillus stearothermophillus adalah 50\% (Gambar 7), dimana pada konsentrasi tersebut tidak terdapat pertumbuhan bakteri.
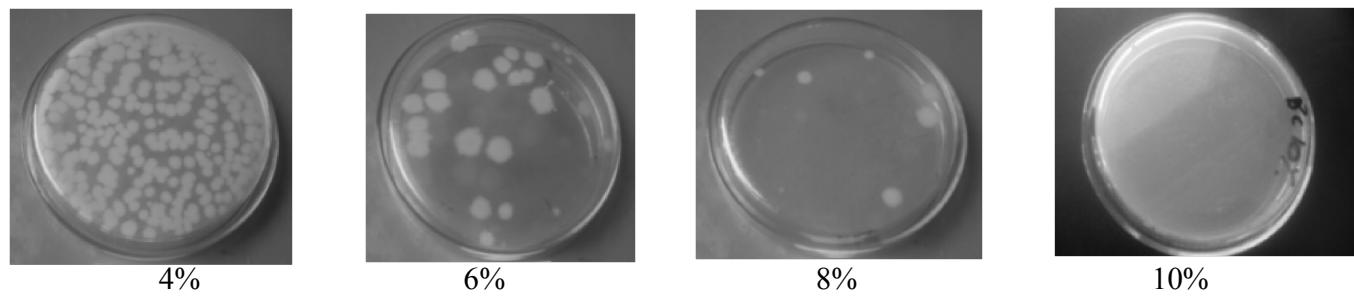

$10 \%$

Gambar 6. Hasil inkubasi Bacillus cereus pada media NB dengan antibakteri ekstrak angkak yang Jernih) ditumbuhkan pada media NA

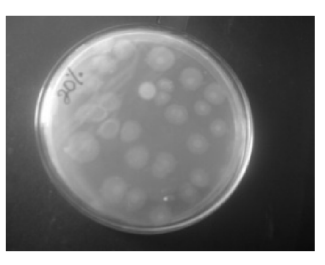

$20 \%$

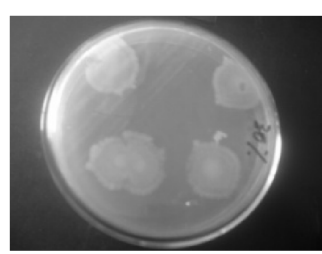

$30 \%$

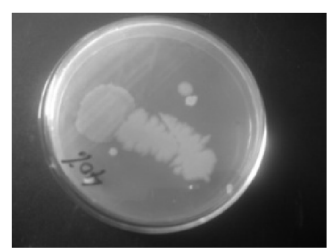

$40 \%$

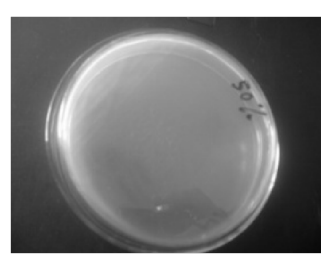

$50 \%$

Gambar 7. Hasil inkubasi Bacillus stearothermophillus pada media NB dengan antibakteri ekstrak angkak (yang jernih) ditumbuhkan pada media NA 
KHM terhadap bakteri Bacillus cereus lebih rendah dibadingkan KHM terhadap bakteri Bacillus stearothermophilus. Hal ini disebabkan Bacillus cereus adalah jenis bakteri patogen dan merupakan bakteri gram positif. Sedangkan bakteri Bacillus stearothermophilus adalah bakteri pembusuk yang tahan panas. Angkak memiliki aktivitas sebagai antibakteri karena adanya senyawa Monascidin A, yaitu senyawa yang bersifat antibiotik yang mampu menghambat bakteri dari genus Bacillus. Bakteri Bacillus adalah bakteri gram positip. Adanya aktivitas antibakteri tersebut memungkinkan adanya efek preservatif dari penggunaan pada produk fermentasi Monascus ( Behr, 1998). Mekanisme yang diduga adalah Bakteri gram positip dapat terhambat pertumbuhannya karena bakteri ini tersusun atas peptidoglikan, adanya Monascidin $A$. akan mengganggu komponen penyusun peptidoglikan sehingga lapisan dinding sel tidak terbentuk secara utuh dan kemudian mengalami lisis yang akhirnya menyebabkan kematian ( Robinson, 1991) .

Perbedaan sensitivitas bakteri terhadap antibakteri dipengaruhi oleh

\section{KESIMPULAN DAN SARAN}

\section{Kesimpulan}

Dari hasil penelitian dapat disimpulkan bahwa :

a. Ekstrak beras angkak mempunyai aktivitas antibakteri terhadap Bacillus cereus dan Bacillus stearothermophillus.

b. Nilai Kadar Hambat Minimum (KHM) Ekstrak beras angkak terhadap Bacillus cereus adalah struktur dinding sel bakteri. Bacillus cereus adalah bakteri gram positif. Bakteri gram positif cenderung lebih sensitif terhadap antibakteri, karena struktur dinding sel bakteri gram positif lebih sederhana dibandingkan struktur dinding sel bakteri gram negatif sehingga memudahkan senyawa antibakteri untuk masuk kedalam sel bakteri gram positif. Bakteri gram positip dapat terhambat pertumbuhannya karena bakteri ini tersusun atas peptidoglikan, adanya Monascidin A. akan menghambat pembentukan peptidoglikan yang utuh sehingga dinding sel bakteri akhirnya mengalami lisis. Sedangkan Bacillus stearothermophilus, merupakan anggota kelompok bakteri gram negatif, mempunyai membrane luar yang tersusun atas lipopolisakarida, lipoprotein, dan lipofosfat yang melindungi lapisan tipis dari peptidoglikan. Hal ini menyebabkan bakteri gram negatip lebih tahan terhadap antimikroba Monascidin A.( Tortara, et al. 1995). Oleh karena itu maka dinding sel Bacillus cereus lebih sensitive terhadap antibakteri. Hal inilah yang menyebabkan KHM dan KBM terhadap Bacillus stearothermophilus lebih tinggi .

konsentrasi $4 \% \quad b / v$ dan untuk Bacillus stearothermophillus adalah konsentrasi $20 \%$ b/v.

c. Nilai Kadar Bunuh Minimum (KBM) Ekstrak beras angkak terhadap Bacillus cereus adalah konsentrasi $10 \% \quad b / v$ dan untuk Bacillus stearothermophillus adalah konsentrasi $50 \%$ b/v. 


\section{Saran}

a. Perlu dilakukan uji aktivitas antibakteri ekstrak angkak terhadap jenis bakteri yang lain

\section{DAFTAR PUSTAKA}

Berhr, W. 1998. Monascus purpureuBonn.Retrieved from ww.behrbonn.com/literat/ monascuccub.htm

Danuri, H. 2008. Optimizing Angkak Pigment and Lovastatin Production by Monascus purpureus. Journal of Bioscience 15(2): 61-66.

Davis, W.W. dan T.R. Stout. 1971. Disc Plate Methods of Microbiological Antibiotic Assay. Microbiology 22:659-665.

Hermawan, A., Hana, W., dan Wiwiek, T. 2007. Pengaruh Ekstrak Daun Sirih (Piper betleL.) Terhadap Pertumbuhan Staphylococcus aureus dan Escherichia coli dengan Metode Difusi Disk. UniversitasErlangga.

Hogg S. 2005. Essential Microbiology. West Sussex: John Wiley \& Sons Ltd.

Jenie, B.S.L, Mitrajanty, K.D, dan Fardiaz, S. 1997. Produksi Konsentrat dan Bubuk Pigmen Angkak dari Monascus purpureus serta Stabilitasnya selama Penyimpanan. Bul.Teknol. dan Industri Pangan 8(2): 39-46.

Juliantina, F. R., Ayu, D. C. M, dan Nirwani, B. 2008. Manfaat Sirih Merah (Piper crocatum) sebagai Agen Antibakterial Terhadap Bakteri Gram Positif dan Gram Negatif. Jurnal Kedokteran dan Kesehatan Indonesia.

Kusmayati dan Agustini, N. W. R. 2007. Uji Aktivitas Senyawa b. Perlu dilakukan penelitian lebih lanjut terhadap daya simpan produk yang menggunakan ekstrak angkak sebagai pengawet.
Antibakteri dari Mikro alga (Porphyridium cruentum).
Biodiversitas. 8(1) : 48-53.

Madigan M.2005. Brock Biology of Microorganisme. Hlmn :753. London: PrenticeHall.

Pratiwi, Sylvia. T. 2008. Mikrobiologi Farmasi. Penerbit Erlangga, Jakarta.Peter. 2005. Chemical Constituents and Noni's Function. Noni News Indian Magazine. Edisi Oktober (2) X.

Pratiwi, I. 2009. Uji Antibakteri Ekstrak Kasar Daun Acalypha indica terhadap Bakteri Salmonella choleraesuis dan Salmonella typhimurium. Skripsi. Jurusan Biologi FMIPA UNS, Surakarta

Siswando, Soekardjo B. 1995. Kimia Medisinal. Surabaya: Airlangga Univ Pr.

Timotius, K.H. 2004. Produksi Pigmen Angkak oleh Monascus. Jurnal Teknol. Dan Industri Pangan 15(1): 79-86.

Todar. K. 2008. Bacillus cereus Keracunan Makanan. www.textbookofbacteriology.net [22 Oktober 2009].

Robinson,T. 1991. Kandungan Organik Tumbuhan Tingkat Tinggi. Diterjemahkan oleh Prof.Dr. Kosasih Padmawinata. Penerbit ITB Bandung. 
Jurnal Teknologi Pangan Vol.6 No.1

Januari 2015

Steinkraus, H. 1983. Indegenous

FermentedSumaryati Enny dan

Sudiyono. 2012. Isolasi pigmen merah hasil biosintesa angkak oleh Monascus purpureus dalam mediumPati ubijalar dan bungkil kacang tanah. Program Studi Teknologi Hasil Pertanian.

Universitas Widyagama Malang. 